\title{
MEASURING COMPETITIVENESS IN TOURISM ENTERPRISES USING INTEGRAL INDEX
}

\author{
Bahodirhon SAFAROV* \\ Samarkand State University, Faculty of Human Resources Management, \\ Department of Digital Economy, Uzbekistan, e-mail: safarovb@rambler.ru \\ Bekzot JANZAKOV \\ Samarkand State University, Faculty of Human Resources Management, \\ Department of Digital Economy, Uzbekistan, e-mail: samstateuniv.econ@ gmail.com
}

\begin{abstract}
Citation: Safarov, B., \& Janzakov, B. (2021). MEASURING COMPETITIVENESS IN TOURISM ENTERPRISES USING INTEGRAL INDEX. GeoJournal of Tourism and Geosites, 37(3), 768-774. https://doi.org/10.30892/gtg.37305-707
\end{abstract}

\begin{abstract}
The study aims to develop the methodology of measuring competitiveness in the context of tourism enterprises. The normalization method was used to construct the integral index of competitiveness which was aggregated by 13 sub indicators. In the process of obtaining sub indicators the methods of survey and face to face interviews were used. This study recommends new method of measuring competitiveness in the context of tourism enterprises uniting human resources, service quality competitiveness, market share, and profit benchmark in one integral index. This index can be used by regional tourism destination management bodies to make better decisions regarding sustainable development of tourism destination.
\end{abstract}

Key words: competitiveness, tourism, index, infrastructure, services, marketshare, system of indicators

\section{INTRODUCTION}

The need for high-quality tourism services today is growing with the rise of living standards, and the development of tourism culture. At the same time, in addition to delivering traditional services to tourists, sharing new experiences, events that will make them return, amazing adventure tours and other creative ideas serve to increase the flow of tourists in tourism destinations. The Covid-19 pandemics has had a deep effect on tourism as a whole. According to Matiza and Slabbert (2021) the pandemics increased physical, psychological and social risk perception on specific tourism activities. In the studies of Wang and Ackerman, 2019 was found out that perceived infection risk was associated with safety concerns and thereby negatively affected group-tourism oriented activity. Although the effect of Covid-19 on competitiveness is huge, Matiza and Slabbert (2021) suggest using product innovations which should be accompanied by government support in implementing integrated crisis communications marketing strategy thereby ensuring the aggregate competitiveness of tourism destination. The competitiveness of the tourism industry can be studied at the macro and micro levels. At the macro level, competitiveness reflects the state of tourism destinations, the conditions created for the organization of tourism business in countries, the economic situation, specific resources, etc., in relation to other competitive destinations (Goffi et al., 2019). The World Economic Forum annually publishes the Tourism Competitiveness Index for 136 countries. The Tourism Competitiveness Index is a more comprehensive indicator, consisting of four main factors and 14 sub-factors.

Questionnaires and statistical data analysis for each factor are performed and evaluated on a scale from 1 to 7 . Four main factors: the shaping environment, tourism policy and conditions, infrastructure, and natural cultural resources create opportunities for tourism. The shaping environment means the convenience of the business environment, security, availability of qualified medical services, the number of qualified personnel and the availability of information technology infrastructure, which are the most important for the organization of tourism. The factor of tourism policy and conditions reflects the extent to which tourism is supported by the state, freedom of economic resources, price competitiveness of tourism enterprises and the environmental situation in tourism areas. The infrastructure factor plays a key role in serving tourists. This factor reflects the condition of the airline infrastructure, the conditions of roads in the country, catering services, hotels and others. Another important factor is the unique natural resources of tourism destination, such as waterfalls, mountains, rivers, and cultural resources: historical monuments, mass cultural enlightenment events, holidays, and so on. Through the competitiveness assessment methodology of the World Economic Forum, the overall competitiveness of tourism destinations can be clearly expressed. However, measuring the competitiveness of tourism enterprises (tour firms, tour operators, tour agents, etc.) that are considered value-creating in the field of tourism requires a completely different approach. That is, the system of indicators at the macro level is not useful. Therefore, a separate methodology is required to assess the competitiveness of services in tourism enterprises.

LITERATURE REVIEW

Among many competitiveness indicators, the most widespread was developed by the World Economic Forum (WEF,

\footnotetext{
${ }^{*}$ Corresponding author
} 
2018) in 2007. This indicator is called as the Travel and Tourism Competitiveness Index (TTCI), which is published regularly and measures the competitiveness of the main tourist destinations worldwide. The goal of the TTCI is to assess factors and policies that make a destination attractive in the eyes of international tourists.

This index is broadly used by many researchers to measure tourism destination competitiveness. For instance, Kendall and Gursoy (2010) explored the relative positioning of eight Mediterranean destinations using a correspondence analysis technique; Gursoy et al., 2009 examined the relative positioning of ten Middle East destinations using a multidimensional scaling analysis; Mashika et al., 2021 investigated sustainable development of hotel, restaurant and tourism business's competitiveness in Ukraine; Kayar and Kozak (2007) compared the competitiveness levels of several European countries with those of Turkey using cluster analysis and multidimensional scaling; Leung and Baloglu (2013) used the same method for sixteen Asia Pacific destinations. Other researchers developed new tourism competitiveness indexes. For example, Gooroochurn and Sugiyarto (2005) used data from the competitiveness monitor scale proposed by the World Travel and Tourism Council, which measures TDC through the development of eight key indicators, using confirmatory factor analysis, in order to calculate an aggregate index Croes (2011) developed more accurate TDC index, using the most important factors affecting the competitiveness of island tourism destinations; Croes and Kubickova (2013) suggested an alternative competitiveness index, which they apply to the Central American region. Others authors have focused their attention on analyzing different approaches in tourism competitiveness (Dwyer et al., 2014; Sainaghi et al., 2017). Some researches examined common factors that affect tourism competitiveness (Reisinger et al., 2019; Kozegar et al., 2017), whereas others evaluated the effect of specific factors such as the evolution of tourist inflows (De la Pena et al., 2019); globalization (Ivanov and Webster, 2013); tourism's contribution to economic growth (Webster and Ivanov, 2014); corruption (Das and Dirienzo, 2010); air transportation (Khan et al., 2017); the competitiveness of international hotel firms (Mendieta-Penalver, 2018; Janzakov, 2019); regional systems of innovation (Romão and Nijkamp, 2019; Safarov, 2016) These studies demonstrated the problems of measuring competitiveness with TDC and suggested various ways of improving the competitiveness index in certain contexts.

\section{MATERIALS AND METHODS}

The method of normalization was used to integrate various indicators into one integral index. Also, face to face interviews with 15 company managers, and surveys with 150 tourists were conducted from May 2019 to September 2019 in Samarkand city, Uzbekistan. Walesiak (2018) highlighted the use of normalization method in constructing composite indicators. From his research it can be concluded that normalized composite indicators can effectively model the aggregate changes of economic variables. Based on this, we used the method of normalization in constructing integral index of competitiveness. At first, we examined the reviews from tripadvisor.com, and booking.com for 16 hotels in Samarkand. The next step was to analyze the perceptions of tourists. We went to main tourism sites: Registan square, and Gur Emir Mausoleum, and there we randomly surveyed 5-10 people a day. In total, we spend three months conducting surveys. The survey was very short and consisted of following questions:

1) In which hotel are you staying now?

2) How do you rate service quality in your hotel? Answer options: poor, good, excellent;

3) How do you rate prices for services? Answer options: very high, ok, very cheap;

4) How do you rate website of the hotel and innovativeness of services? Answer options: poor, good, excellent;

5) Please indicate the way you found out about this hotel or tourism company?

Answer options: TV ad, radio, billboard, friend recommendation, internet, other. Having finished surveys, the next step was to evaluate services from supply point of view. We went to 15 largest hotels and tour companies in Samarkand, and interviewed hotel managers and some of their staff. During interviews we asked following questions:

1) How long have you been working for this company?

2) How long is your experience in tourism industry in months?

3) Have you graduated from higher educational institution?

4) In what range your monthly salary fall? Answer options: below 100 US dollars, between 100 and 500 US dollars, and above 500 US dollars.

5) How often do you have to hire new employees?

6) Do you imagine yourself working here after five years?

After finishing with interviews, we aggregated the results and calculated the indices of quality and personnel competitiveness. For indices of market share and financial competitiveness we used data from department of statistics of Samarkand region. In order to calculate the integral competitiveness index the method of normalized aggregation was used.

\section{RESULTS AND DISCUSSION}

The competitiveness of tourism services is inextricably linked, first of all, with the level of development of tourism infrastructure. Tourism infrastructure is a variety of equipment, machinery and services used by tourists (Panasiuk, 2007). It consists of the following parts:

1) accommodation facilities: hotels, hostels, guest houses, boarding houses, etc;

2) catering services: restaurants, cafe, bars, kitchens, etc;

3) transport services in the destination;

4) recreation and entertainment services: ski resorts, swimming pools, golf clubs, etc;

5) retail services; 
6) other services: information bureau services, rental of various equipment and vehicles, and other services.

In our analysis of the factors affecting competitiveness, we have assumed that the infrastructure is sufficiently developed to arrange tourism. This approach allows us to measure other important factors that affect competitiveness and to develop an integral competitiveness index based on this. In the process of development of the competitiveness index, we proposed a system of indicators such as the profit benchmark, the quality of services identified as the result of feedback, the company's share in the tourism market and staff competitiveness. Thus, we recommend the use of the following system of indicators to determine the competitiveness of services in tourism enterprises (Table 1).

Table 1. The system of indicators of competitiveness

\begin{tabular}{|c|c|c|}
\hline \multicolumn{3}{|c|}{ Financial competitiveness of the enterprise } \\
\hline Indicator name & Formulas & Description \\
\hline $\begin{array}{l}\text { Net profit of the } \\
\text { enterprise }\end{array}$ & $\begin{array}{l}F=D-X \\
D \text { is the total income of the enterprise; } \\
X \text { - is total cost. }\end{array}$ & $\begin{array}{l}\text { Represents the amount } \\
\text { of money an enterprise } \\
\text { can spend }\end{array}$ \\
\hline $\begin{array}{l}\text { fit } \\
\text { arking }\end{array}$ & $\begin{array}{l}K_{f}=\frac{F_{g f e s}}{F_{\max }} \\
K_{f}-\text { Benchmarking of the profit of the tourist enterprise } \\
F_{\text {given }} \text { - annual profit of the given enterprise; } \\
F_{\text {max }}-\text { annual profit of the biggest enterprise. }\end{array}$ & $\begin{array}{l}\text { Reflects the change in } \\
\text { net profit relative to the } \\
\text { profit of the largest } \\
\text { enterprise in the market. }\end{array}$ \\
\hline \multicolumn{3}{|c|}{ Competitiveness of the enterprise on service quality } \\
\hline $\begin{array}{l}\text { The share of customers } \\
\text { in the total number of } \\
\text { customers who rated the } \\
\text { service as good quality }\end{array}$ & 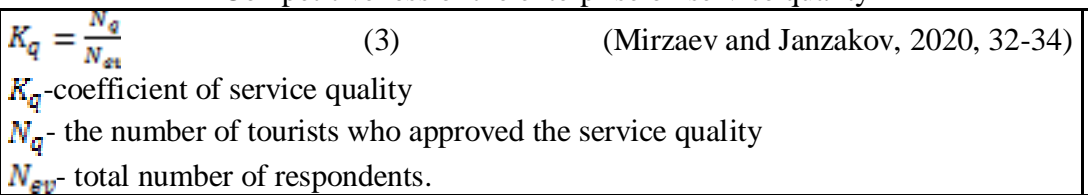 & $\begin{array}{l}\text { Represents the level of } \\
\text { quality of service }\end{array}$ \\
\hline $\begin{array}{l}\text { The ratio of the quality } \\
\text { of services provided to } \\
\text { the performance of the } \\
\text { largest competitor in } \\
\text { the market }\end{array}$ & $\begin{array}{l}K_{\text {rel }}=\frac{K_{0}^{a}}{K_{1}^{Q}} \\
K_{\text {rel }}-\text { The value of the quality of service at the enterprise in relation to a competing } \\
\text { enterprise; } \\
K_{0}^{q} \text { - service quality ratio at the enterprise; } \\
K_{1}^{q} \text {-coefficient of service quality in the largest competitor. }\end{array}$ & $\begin{array}{l}\text { The quality of service } \\
\text { provided by the } \\
\text { company reflects its } \\
\text { value in relation to the } \\
\text { quality of service } \\
\text { provided by competitors. }\end{array}$ \\
\hline $\begin{array}{l}\text { Competitiveness } \\
\text { service quality }\end{array}$ & $\begin{array}{l}K_{g y}=v_{1} * K_{q}+v_{2} * K_{r e l} \quad \text { (5) } \\
v_{1} \text { and } v_{2} \text { are corresponding weights; } \\
K_{g V}-\text { service quality competitiveness indicator; } \\
K_{\mathrm{q}}-\text { coefficient of service quality; } \\
K_{\mathrm{rel}}-\text { benchmark indicator of service quality. }\end{array}$ & $\begin{array}{l}\text { Reflects the balance } \\
\text { between the market and } \\
\text { the quality of service } \\
\text { (perceived by tourists) } \\
\text { of the enterprise }\end{array}$ \\
\hline \multicolumn{3}{|c|}{ Market share of the enterprise } \\
\hline $\begin{array}{l}\text { The ratio of the number } \\
\text { of tourists served by the } \\
\text { enterprise to the total } \\
\text { number of tourists } \\
\text { served in the area }\end{array}$ & $\begin{array}{l}K_{\text {gerv }}=\frac{N_{\text {gart }}}{N_{\text {fuffer }}} \quad(6) \\
N_{\text {gerv }} \text { nunf of tourists served; } \\
N_{\text {total }} \text { total number of tourists served arrived in the area; } \\
K_{\text {gerv }} \text { - market share of the enterprise. }\end{array}$ & $\begin{array}{l}\text { Shows the company's } \\
\text { current position in the } \\
\text { tourism market }\end{array}$ \\
\hline $\begin{array}{l}\text { The share of } \\
\text { the company's cost of } \\
\text { innovative technologies } \\
\text { in total costs }\end{array}$ & $\begin{array}{l}K_{\text {innov }}=\frac{X_{\text {fritron }}}{X_{\text {rom }}} \\
X_{\text {innov }} \text { Expenditures of enterprises on innovations } \\
X_{\text {total }} \text { - total costs of the enterprise } \\
K_{\text {innov }} \text { the share of innovation costs in total costs. }\end{array}$ & $\begin{array}{l}\text { The indicator reflects } \\
\text { the share of costs } \\
\text { for innovation in } \\
\text { enterprises }\end{array}$ \\
\hline $\begin{array}{l}\text { The share of marketing } \\
\text { expenses in total } \\
\text { expenses }\end{array}$ & $\begin{array}{l}K_{m y}=\frac{X_{m F}}{X_{\mathrm{roral}}} \\
X_{m F} \text {-expenses on marketing expenses of the enterprise (advertising services, posters, } \\
\text { stands, etc.); } \\
X_{\mathrm{total}} \text { - total costs of the enterprise; } \\
K_{\mathrm{mr}} \text { - The share of marketing costs in total costs. }\end{array}$ & $\begin{array}{l}\text { Represents the share of } \\
\text { marketing expenses in } \\
\text { an enterprise. }\end{array}$ \\
\hline $\begin{array}{l}\text { The market share of the } \\
\text { enterprise }\end{array}$ & $\begin{array}{l}K_{m s}=W_{1} * K_{g a r v}+W_{2} * K_{\text {innov }}+W_{a d} * K_{m y} \quad(9) \quad(\text { Safarov, 2020, 121-123) } \\
K_{m s} \text {-integrated coefficient of the enterprise's market share. } \\
W_{1 s} W_{2,} W_{2}-\text { appropriate weights. }\end{array}$ & $\begin{array}{l}\text { Represents the stability } \\
\text { of market share. }\end{array}$ \\
\hline \multicolumn{3}{|c|}{ Personnel competitiveness } \\
\hline $\begin{array}{l}\text { The share of qualified } \\
\text { employees in the total } \\
\text { number of employees } \\
\text { in the enterprise }\end{array}$ & $\begin{array}{l}K_{\text {qgh }}=\frac{N_{q}}{N} \quad(10) \quad \text { (Mirzaev and Janzakov, 2020, 42-44) } \\
N_{q^{-}} \text {number of qualified employees in the enterprise; } \\
N_{\text {total }} \text { total number of employees; } \\
K_{\text {ggh }} \text {-share of qualified staff. }\end{array}$ & $\begin{array}{l}\text { Reflects the shar } \\
\text { qualified staff in } \\
\text { employees. }\end{array}$ \\
\hline $\begin{array}{l}\text { The ratio of the average } \\
\text { salary of employees in } \\
\text { an enterprise to the } \\
\text { average salary of } \\
\text { employees of the largest } \\
\text { competing enterprise. }\end{array}$ & $\begin{array}{l}K_{\text {wage }}=\frac{I_{\text {waga }}}{I_{\text {Wam }}} \quad \text { (11) } \\
I_{\text {wage }} \text { The average salary of employees at the enterprise; } \\
I_{\text {wagemax }} \text { - the average salary of employees in the biggest competing enterprise; } \\
K_{\text {wage-reflects the competitiveness of salaries in the enterprise. }}\end{array}$ & $\begin{array}{l}\text { Reflects the } \\
\text { competition for } \\
\text { personnel between } \\
\text { enterprises }\end{array}$ \\
\hline
\end{tabular}




\begin{tabular}{|c|c|c|}
\hline Personnel turnover ratio & $\begin{array}{l}K_{\text {twrnover }}=\frac{N_{L S}}{N_{\text {trof }}} \quad \text { (12) Mirzaev and Janzakov, 2020, 42-44) } \\
N_{l s} \text {-the number of employees that left company; } \\
N_{\text {totall }} \text { the number of employees who have worked and are still working in the company; } \\
K_{\text {twmover }} \text {-coefficient of staff turnover. }\end{array}$ & $\begin{array}{l}\text { Reflects how quickly } \\
\text { staff changes in the } \\
\text { company. }\end{array}$ \\
\hline $\begin{array}{l}\text { Personnel } \\
\text { competitiveness ratio }\end{array}$ & $\begin{array}{l}K_{p e}=u_{1} * K_{q g h}+u_{2} * K_{\text {wage }}-u_{\mathrm{a}} * K_{\text {turnover }}(13) \text { (Mirzaev and Janzakov, 2020, 42-44) } \\
K_{p e}-\text { personnel competitiveness ratio; } \\
K_{q \varepsilon h}-\text { share of qualified staff; } \\
K_{\text {wage }}-\text { average wage benchmark; } \\
u_{1 v} u_{2,} u_{a}-\text { appropriate weights. }\end{array}$ & $\begin{array}{l}\text { Represent effectiveness } \\
\text { of the company's } \\
\text { human resources } \\
\text { policy. }\end{array}$ \\
\hline $\begin{array}{l}\text { Integrated } \\
\text { Competitiveness Index }\end{array}$ & $\begin{array}{l}K_{\text {ici }}=\sum_{\mathrm{i}=1} x_{\mathrm{i}} * N_{\mathrm{i}} \\
x_{\mathrm{i}}-\text { the value of the } i \text { th indicator; } \\
K_{\text {ici }}-\text { integrated competitiveness index; } \\
N_{\mathrm{i}}=\frac{1}{\max _{\mathrm{i}}-\min _{\mathrm{i}}}-\text { standardized normal coefficient of the } i \text { th indicator; (Walesiak, 2018) } \\
\max _{\mathrm{i}} \text { - the maximum value of the indicator } i \\
\min _{\mathrm{i}} \text { - the minimum value of the indicator } i \text {. }\end{array}$ & $\begin{array}{l}\text { Reflects the } \\
\text { sustainability of the } \\
\text { enterprise's } \\
\text { competitiveness }\end{array}$ \\
\hline
\end{tabular}

We developed an integral competitiveness index consisting of 13 sub-indicators measuring activities of tourism enterprises. Two indicators represent the financial competitiveness of the tourism enterprise, 3 indicators represent competitiveness in quality, 4 indicators show the company's market share, and 4 indicators represent staff competitiveness.

The financial competitiveness reflects the degree of financial stability of the tourism enterprise in the current competitive environment. We suggested that the benchmark of the profit of an enterprise, which can be calculated by dividing the given profit to the profit of the largest competitor, can be a good indicator of financial competitiveness.

The competitiveness of the quality of tourism services is one of the key factors in achieving a competitive advantage for tourism enterprises. Tourism service quality can be roughly assessed by dividing the number of tourists that positively evaluated service to the total number of tourists. Then we divide the quality indicator of the given enterprise to the quality indicator of the largest competitor's. That is, we determine the state of quality of tourism services in the enterprise relative to the market. Then based on expert assessment we assign weights to the benchmark quality indicator and quality indicators given by tourists. Thereby the index for service quality competitiveness can be calculated. So as to get expert assessment, we conducted face to face interviews with 15 managers of various tourism companies.

Table 3. The methodology of calculating the competitiveness index of service quality

\begin{tabular}{|l|c|c|c|}
\hline \multicolumn{1}{|c|}{$\begin{array}{c}\text { Tourism } \\
\text { enterprises }\end{array}$} & $\begin{array}{c}\text { The share } \\
\text { of tourists } \\
\text { that } \\
\text { approved } \\
\text { tourism } \\
\text { service (1) }\end{array}$ & $\begin{array}{c}\text { The ratio of the } \\
\text { given approval } \\
\text { index to the } \\
\text { approval index } \\
\text { of the biggest } \\
\text { competitor (2) }\end{array}$ & $\begin{array}{c}\text { The } \\
\text { competitiven } \\
\text { ess index of } \\
\text { service } \\
\text { quality (0.6* } \\
\left.(1)+0.4^{*}(2)\right)\end{array}$ \\
\hline LLC "Sogda tur" & 0.6 & 0.67 & 0.63 \\
\hline Ekspri-Dyutemp & 0.65 & 0.73 & 0.68 \\
\hline XSIChF Shark & 0.8 & 0.90 & 0.84 \\
\hline uzb. For.yu & 0.6 & 0.67 & 0.63 \\
\hline Timur & 0.7 & 0.79 & 0.73 \\
\hline Starlight & 0.4 & 0.45 & 0.42 \\
\hline Sarbon tour & 0.84 & 0.94 & 0.88 \\
\hline Orient-Star hotel & 0.75 & 0.84 & 0.79 \\
\hline Nusratillo & 0.65 & 0.73 & 0.68 \\
\hline Lejand & 0.88 & 0.99 & 0.92 \\
\hline Crown & 0.56 & 0.63 & 0.59 \\
\hline KATIA & 0.69 & 0.78 & 0.72 \\
\hline Caravan & 0.7 & 0.79 & 0.73 \\
\hline Jamshed & 0.62 & 0.70 & 0.65 \\
\hline Darvesh & 0.63 & 0.71 & 0.66 \\
\hline Barak & 0.77 & 0.87 & 0.81 \\
\hline Samintur & 0.83 & 0.93 & 0.87 \\
\hline Mauzo & 0.82 & 0.92 & 0.86 \\
\hline Samarkand plaza & 0.72 & 0.81 & 0.76 \\
\hline Sogda tennis ball & 0.3 & 0.34 & 0.31 \\
\hline Alijon & 0.66 & 0.74 & 0.69 \\
\hline Grand Samarkand & 0.68 & 0.76 & 0.71 \\
\hline Salom trevl service & 0.74 & 0.83 & 0.78 \\
\hline Konstantin & 0.89 & 1.00 & 0.93 \\
\hline Malika & 0.79 & 0.89 & 0.83 \\
\hline & & & \\
\hline
\end{tabular}

Table 4. The methodology of calculating market share index

\begin{tabular}{|l|c|c|c|c|}
\hline Tourism enterprises & $\begin{array}{c}\text { The ratio of } \\
\text { number served } \\
\text { tourists by the } \\
\text { given enterprise } \\
\text { to the total number } \\
\text { of tourists in the } \\
\text { area (1) }\end{array}$ & $\begin{array}{c}\text { The share } \\
\text { of expenses } \\
\text { on innovation } \\
\text { in total } \\
\text { cost of an } \\
\text { enterprise } \\
(2)\end{array}$ & $\begin{array}{c}\text { The share } \\
\text { of } \\
\text { marketing } \\
\text { expenses } \\
\text { to total } \\
\text { expenses } \\
(3)\end{array}$ & $\begin{array}{c}\text { The } \\
\text { market } \\
\text { share } \\
\text { index } \\
\left(0.8^{*}(1)\right. \\
+0.1^{*}(2)+ \\
+0.1^{*}(3)\end{array}$ \\
\hline LLC "Sogda tur" & 0.05 & 0.01 & 0.11 & 0.05 \\
\hline Ekspri-Dyutemp & 0.03 & 0.02 & 0.02 & 0.02 \\
\hline XSIChF Shark & 0.03 & 0.01 & 0.03 & 0.03 \\
\hline uzb. For.yu & 0.02 & 0 & 0.1 & 0.02 \\
\hline Timur & 0.02 & 0 & 0 & 0.02 \\
\hline Starlight & 0.03 & 0 & 0 & 0.02 \\
\hline Sarbon tour & 0.04 & 0.05 & 0.13 & 0.05 \\
\hline Orient-Star hotel & 0.19 & 0.06 & 0.11 & 0.17 \\
\hline Nusratillo & 0.01 & 0 & 0 & 0.01 \\
\hline Lejand & 0.04 & 0 & 0.9 & 0.12 \\
\hline Crown & 0.01 & 0 & 0 & 0.00 \\
\hline KATIA & 0.05 & 0.1 & 0.15 & 0.07 \\
\hline Caravan & 0.03 & 0.03 & 0 & 0.02 \\
\hline Jamshed & 0.02 & 0 & 0 & 0.01 \\
\hline Darvesh & 0.02 & 0 & 0 & 0.01 \\
\hline Barak & 0.01 & 0 & 0 & 0.01 \\
\hline Samintur & 0.02 & 0 & 0 & 0.02 \\
\hline Mauzo & 0.02 & 0.1 & 0.03 & 0.03 \\
\hline Samarkand plaza & 0.02 & 0 & 0.01 & 0.02 \\
\hline Sogda tennis ball & 0.02 & 0 & 0 & 0.01 \\
\hline Alijon & 0.03 & 0.01 & 0.01 & 0.03 \\
\hline Grand Samarkand & 0.03 & 0 & 0 & 0.02 \\
\hline Salom trevl service & 0.01 & 0 & 0.5 & 0.06 \\
\hline Konstantin & 0.03 & 0.05 & 0.01 & 0.03 \\
\hline Malika & 0.10 & 0.1 & 0 & 0.09 \\
\hline
\end{tabular}


For general perception of service quality we observed the 25 tourism companies in tripadvisor.com and booking.com in Samarkand region. Also, we conducted survey with 150 tourists out of whom, 36 were international tourists and the rest were internal tourists. The results of the survey are given in the Table 3 . The market share of the enterprise is an important indicator in the formation and maintenance of competitiveness. We determined it as the weighted sum of the ratio of served tourists to the total number of tourists, innovation expenses on the total cost, and marketing expenses on total cost. Innovation and marketing expenses are usually directed to gain a competitive advantage over other competitor, therefore we included these indicators as the base for integral market-share stability index (Table 4).

Personnel competitiveness has a direct impact on the competitiveness of the tourism enterprise. We determined this indicator as the weighted sum of the ratio of the number of qualified employees to the total number of employees, and the ratio of the average salary of employees to the average salary of employees of the largest competitors, but minus staff turnover coefficients. In the Table 5 the detailed methodology of the calculation process is given.

\begin{tabular}{|c|c|c|c|c|}
\hline $\begin{array}{l}\text { Tourism } \\
\text { enterprises }\end{array}$ & $\begin{array}{l}\text { The share } \\
\text { of the } \\
\text { number of } \\
\text { qualified } \\
\text { staff to the } \\
\text { total } \\
\text { number of } \\
\text { staff (1) }\end{array}$ & $\begin{array}{l}\text { The ratio of the } \\
\text { average wage } \\
\text { of the staff in } \\
\text { the given } \\
\text { enterprise to } \\
\text { the average } \\
\text { wage of the } \\
\text { staff in the } \\
\text { largest } \\
\text { competitor (2) }\end{array}$ & $\begin{array}{c}\text { Coefficient } \\
\text { of staff } \\
\text { turnover } \\
(3)\end{array}$ & $\begin{array}{c}\text { The index of } \\
\text { personnel } \\
\text { competitive } \\
\text { ness } \\
(1)^{*} 0.7+0.2 \\
*(2)- \\
0.1 *(3)\end{array}$ \\
\hline \begin{tabular}{|l|} 
LLC "Sogda \\
tur"
\end{tabular} & 0.9 & 0.7 & 0.5 & 0.72 \\
\hline \begin{tabular}{|l|} 
Ekspri- \\
Dyutemp
\end{tabular} & 0.8 & 0.6 & 0.6 & 0.62 \\
\hline \begin{tabular}{|l|} 
XSIChF \\
Shark \\
\end{tabular} & 0.7 & 0.9 & 0.8 & 0.59 \\
\hline uzb. For.yu & 1 & 1.02 & 0.3 & 0.874 \\
\hline Timur & 1 & 1.05 & 0.6 & 0.85 \\
\hline \begin{tabular}{|l|} 
Starlight \\
\end{tabular} & 1 & 0.85 & 0.3 & 0.84 \\
\hline Sarbon tour & 0.9 & 0.8 & 0.8 & 0.71 \\
\hline \begin{tabular}{|l|} 
Orient- \\
Star hotel \\
\end{tabular} & 0.8 & 1 & 0.6 & 0.7 \\
\hline Nusratillo & 0.66 & 0.9 & 0 & 0.642 \\
\hline Lejand & 0.5 & 0.8 & 0.6 & 0.45 \\
\hline Crown & 1 & 2 & 0 & 1.1 \\
\hline KATIA & 0.9 & 0.9 & 0.3 & 0.78 \\
\hline \begin{tabular}{|l|} 
Caravan \\
\end{tabular} & 0.7 & 1 & 0 & 0.69 \\
\hline \begin{tabular}{|l|} 
Jamshed \\
\end{tabular} & 1 & 1 & 0.4 & 0.86 \\
\hline \begin{tabular}{|l|} 
Darvesh \\
\end{tabular} & 0.6 & 0.7 & 1 & 0.46 \\
\hline \begin{tabular}{|l|} 
Barak \\
\end{tabular} & 0.8 & 0.6 & 1 & 0.58 \\
\hline \begin{tabular}{|l} 
Samintur \\
\end{tabular} & 0.6 & 0.8 & 1 & 0.48 \\
\hline Mauzo & 0.9 & 0.7 & 0.6 & 0.71 \\
\hline \begin{tabular}{|l|}
$\begin{array}{l}\text { Samarkand } \\
\text { plaza }\end{array}$ \\
\end{tabular} & 0.9 & 0.9 & 0.8 & 0.73 \\
\hline $\begin{array}{l}\text { Sogda tennis } \\
\text { bal }\end{array}$ & 0.3 & 1 & 0.7 & 0.34 \\
\hline \begin{tabular}{|l|} 
Alijon \\
\end{tabular} & 0.6 & 0.8 & 0.5 & 0.53 \\
\hline \begin{tabular}{|l} 
Grand \\
Samarkand
\end{tabular} & 0.5 & 0.7 & 0.3 & 0.46 \\
\hline \begin{tabular}{|l|}
$\begin{array}{l}\text { Salom trevl } \\
\text { service }\end{array}$ \\
\end{tabular} & 1 & 0.8 & 0.9 & 0.77 \\
\hline Konstantin & 0.6 & 1 & 0.2 & 0.6 \\
\hline Malika & 0.1 & 1 & 0.2 & 0.25 \\
\hline
\end{tabular}

Figure 1. Integrated Competitiveness Index of 25 tourism companies operating in Samarkand region (unit of measurement: standardized z-values) (Source: prepared by authors based on survey data, tripadvisor.com, booking.com reviews, and data of

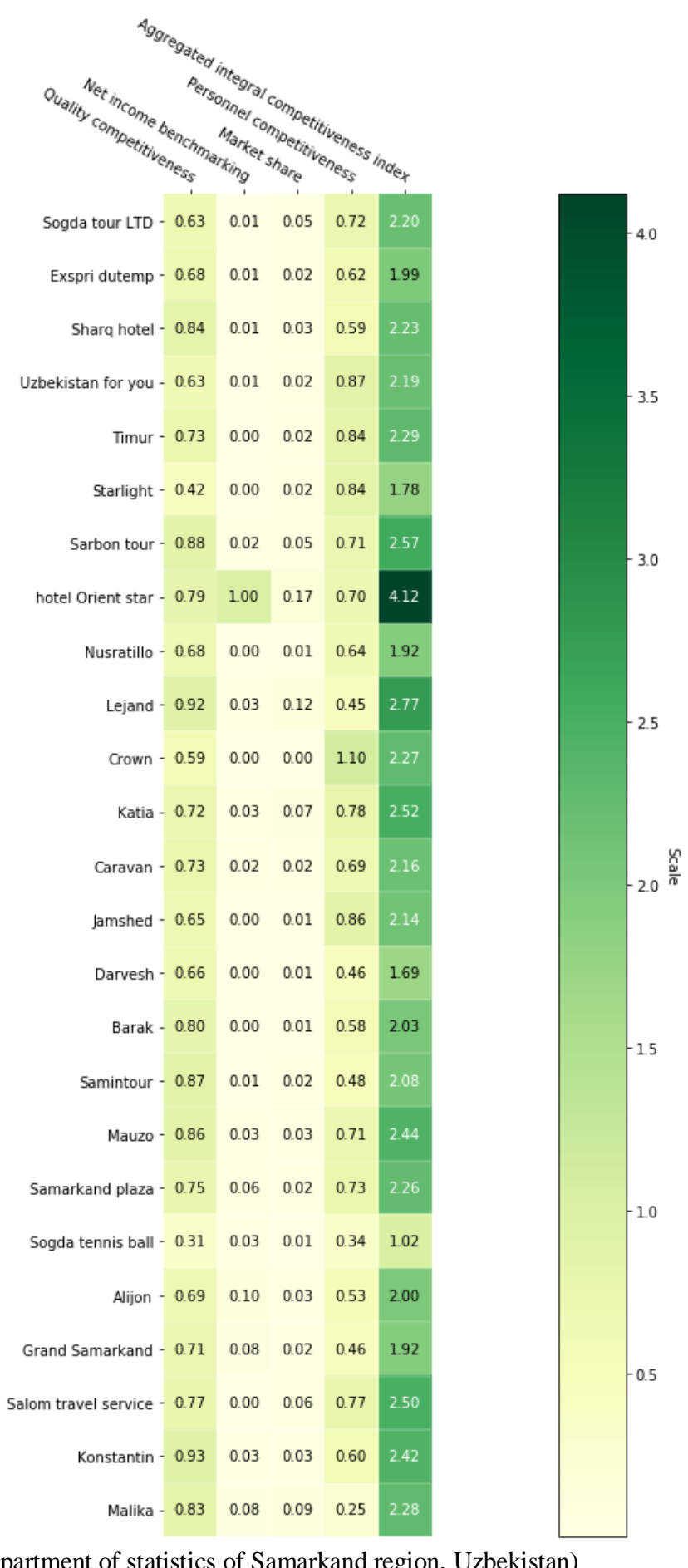

department of statistics of Samarkand region, Uzbekistan)

After calculating the above-mentioned indicators, the integral competitiveness index of the tourism enterprise is calculated using the formula (14). It should be noted that the integral competitiveness index that we propose allows us to determine the 
degree of sustainability of the activities of tourism enterprises in a given period. In addition, it allows one to assess the quality of tourism services, profitability, staff competitiveness, and presence in the market. Using the above indicators, we calculated the integral competitive index for 25 tourism companies and hotels operating in the Samarkand region, Uzbekistan (Figure 1). According to the survey conducted to determine the quality of service in 25 tourism enterprises listed in the figure 1 , nine out of ten tourists who visited the hotel confirmed the high-quality of services in the hotel "Konstantin". The lowest rates were recorded by "Sogda Tennis Ball" and "Starlight" tour companies. Only about $30 \%$ of the customers they served rated the service positively. If we look at the quality competitiveness indicator, 22 tourism enterprises have a score above 0.5 and the difference between them is not large. This, in turn, means that the quality of tourism services in Samarkand is in the similar level. However, the concept of "quality" is relative, and the evaluations are determined by the tastes of individual tourists.

It should be noted that the integral competitiveness indicator cannot be used at the international level. Because the level of development of infrastructure and technologies that we do not take into account has a strong impact on the quality of service. Therefore, in order to be competitive in terms of quality at the international level, first of all, well-developed infrastructure must be built. If we look at market share index, the fact that tourism enterprises recorded relatively low results in terms of the market share means that the tourism market is very competitive. That is, entering and exiting the market does not require large expenditures. According to this indicator, the "Orient Star Hotel" and the "Lejand" tour companies currently serve the largest number of customers. In terms of staff competitiveness, the tour company "Crown" has the highest record.

It was found that all the employees of this company graduated universities, and have been operating since the establishment of the enterprise. The lowest rate was recorded by "Malika" hotel. This hotel performed relatively low results in terms of staff competitiveness due to high staff turnover. The fact that 19 of the 25 companies in the list scored more than 0.5 may indicate that most of the tour companies in the region are competitive in terms of staffing. The integral competitiveness index consists of the above-mentioned indicators, and the highest rate in the Samarkand region was recorded by the hotel "Orient Star". The lowest score was recorded by the tour company "Sogda Tennis Ball".

\section{CONCLUSION}

In conclusion, the integral index competitiveness that we propose can be used by the governing bodies of tourism destinations. This will enable the stakeholders to take timely measures to prevent the emerging or existing issues related to competitiveness in the regional scale.

The essence of this index is that it reflects the availability of sufficient funds, qualified personnel and other resources to compete on an equal footing with other enterprises in various areas of business activity. So, according to our analysis, the most competitive tourism enterprises in Samarkand region are such tour companies as "Orient Star Hotel", "Katia", "Crown", "Sarbon Tour", and "Timur". However, there is still a large gap between the real-world situations and theoretical inferences related to competitiveness. The task of accurately measuring competitiveness may be impossible due to the chaotic character of the processes in markets. Nevertheless, we believe that the proposed methodology of integral competitiveness index will be useful for regional scale management of tourism destinations.

\section{REFERENCES}

Chens, C.Y., Sok, P., \& Sok, K. (2008). Evaluating the competitiveness of the tourism industry in Cambodia: Self-assessment from professionals. Asia Pacific Journal of Tourism Research, 13, 41-66. https://doi.org/10.1080/10941660701883367

Croes, R. (2011). Measuring and explaining competitiveness in the context of small island destinations. Journal of Travel Research, 49(1), 431-442. https://doi.org/10.1177/0047287510368139

Croes, R., \& Kubickova, M. (2013). From potential to ability to compete: Towards a performance-based tourism competitiveness index. Journal of Destination Marketing \& Management, 2, 146-154. https://doi.org/10.1016/j.jdmm.2013.07.002

Das, J., \& Dirienzo, C. (2010). Tourism competitiveness and corruption: A cross-country analysis. Tourism Economics, 16, $477-492$. https://doi.org/10.5367/000000010792278392

De la Peña, M., Núñez-Serrano J.A., Turrión, J., \& Velázquez, F.J. (2019). A New Tool for the Analysis of the International Competitiveness of Tourist Destinations Based on Performance. Journal of Travel Research, 58, $207-223$. https://doi.org/10.1177/0047287517746012

Dwyer, L., Cvelbar, L.K., Mihalic, T., \& Koman, M. (2014). Integrated Destination Competitiveness Model: Testing Its Validity and Data Accessibility. Tourism Analysis, 19(1), 1-17. https://doi.org/10.3727/108354214X13927625340073

Goffi, G., Cucculelli, M., \& Masiero, L. (2019). Fostering tourism destination competitiveness in developing countries: The role of sustainability. Journal of Cleaner Production, 209, 101-115. https://doi.org/10.1016/j.jclepro.2018.10.208

Gooroochurn, N., \& Sugiyarto, G. (2005). Competitiveness indicators in the travel and tourism industry. Tourism Economics, 11, $25-43$. https://doi.org/10.5367/0000000053297130

Gursoy, D., Baloglu, S., \& Chi, C.G. (2009). Destination competitiveness of Middle Eastern countries: An examination of relative positioning, Anatolia, 20, 151-163. https://www.cabdirect.org/cabdirect/abstract/20093169461

Ivanov, S., \& Webster, C. (2013). Globalisation as a driver of destination competitiveness. Annals of Tourism Research, 43, 624-650. https://doi.org/10.1016/j.annals.2013.07.010

Janzakov, B.K. (2019). The impact of hotel location on price offerings in Samarkand city. Journal of Management Value \& Ethics, 10(2), 174-179. http://www.jmveindia.com/journal/OCT-DEC\%2019\%20FINAL.pdf

Kayar, C.H., \& Kozak, N. (2019). Measuring destination competitiveness: An application of the travel and tourism competitiveness index. Journal of Hospitality Marketing \& Management, 19, 203-216. https://doi.org/10.1080/19368621003591319

Kendall, K.W., \& Gursoy, D. (2007). A managerial approach to positioning and branding: Eponymous or efficient. Tourism Analysis, 12, 473-483. https://doi.org/10.3727/108354207783227920 
Khan, S.A.R., Qianli, D., SongBo, W., Zaman, K., \& Zhang, Y. (2017). Travel and tourism competitiveness index: The impact of air transportation, railways transportation, travel and transport services on international inbound and outbound tourism Journal of Air Transport Management, 58, 125-134. https://doi.org/10.1016/j.jairtraman.2016.10.006

Kozegar, L., Hesam, M., \& Kazemi, M. (2017). An analysis of influential factors on tourism destinations competitiveness. Journal of Environmental Management and Tourism, 8, 393-406. https://doi.org/10.14505//jemt.9.2(26).17

Leung, X.Y., \& Baloglu, S. (2013). Tourism competitiveness of Asia Pacific destinations. Tourism Analysis, 18, $371-384$. https://doi.org/10.3727/108354213X13736372325876

Mashika, H., Kudrina, O., Nurgaliyeva, A., Berkova, O., Metil, T., \& Novichkov, V. (2021). Competitiveness of hotel, restaurant and tourism business: factors and tools. GeoJournal of Tourism and Geosites, 36(2spl), 681-687. https://doi.org/10.30892/gtg.362spl16-698

Matiza, T., \& Slabbert, E. (2021). Tourism is too dangerous! Perceived risk and the subjective safety of tourism activity in the era of Covid-19. GeoJournal of Tourism and Geosites, 36(2spl), 580-588. https://doi.org/10.30892/gtg.362spl04-686

Mendieta-Peñalver, L.F., Perles-Ribes, J.F., Ramón-Rodríguez, A.B., \& Such-Devesa, M.J. (2018). Is hotel efficiency necessary for tourism destination competitiveness? An integrated approach. Tourism Economics, 24, 3-26. https://doi.org/10.5367/te.2016.0555

Mirzaev, K., \& Janzakov, B. (2020). The ways of ensuring competitiveness in tourism, LAP LAMBERT Academic Publishing, ISBN-10: 6202795980, 88. https://www.amazon.com/WAYS-ENSURING-COMPETITIVENESS-TOURISM/dp/6202795980

Panasiuk, A. (2007). Tourism infrastructure as a determinant of regional development. - Ekonomika ir vadyba: aktualijos ir perspektyvos. 1 (8), 212-215. ISSN 1648-9098, available at: http://su.lt/bylos/mokslo_leidiniai/ekonomika/7_8/panasiuk.pdf

Reisinger, Y., Michael, N., \& Hayes, J.P. (2019). Destination competitiveness from a tourist perspective: A case of the United Arab Emirates. International Journal of Tourism Research, 21, 259-279. https://doi.org/10.1002/jtr.2259

Romão, J., Nijkamp, P. (2019). Impacts of innovation, productivity and specialization on tourism competitiveness-a spatial econometric analysis on European regions. Current Issues in Tourism, 22, 1150-1169. https://doi.org/10.1080/13683500.2017.1366434

Safarov, B.S. (2016). The role of innovations and its impact on investment flow into tourism market of Uzbekistan. Journal of Economy and Business, 3, 18-22. https://cyberleninka.ru/article/n/rol-innovatsiy-i-ih-znachenie-v-investitsiyah-na-rynke-turistskih-uslug-v-uzbekistane

Safarov, B.S. (2010). The models of prognosis of regional tourism's development. Perspectives of Innovations, Economics \& Business, 6, 80-83. https://www.ceeol.com/search/article-detail?id=246600

Safarov B.S. (2020). Moliya va soliqlar. Textbook for students, Tashkent, Science and technologies, 512, (in Uzbek).

Sainaghi, R., Phillips, P., \& Zavarrone, E. (2017). Performance measurement in tourism firms: A content analytical meta-approach. Tourism Management, 59, 36-56. https://doi.org/10.1016/j.tourman.2016.07.002

Wang, I.M., \& Ackerman, J.M. (2019). The infectiousness of crowds: Crowding experiences are amplified by pathogen threats. Personality and Social Psychology Bulletin, 45(1), 120-132. https://doi.org/10.1177/0146167218780735

Walesiak, M. (2018). The Choice of Normalization method and rankings of the set of objects based on composite indicator value. Statistics in Transition New Series, 19, 693-710, https://doi.org/10.21307/stattrans-2018-036

Webster, C., \& Ivanov, S. (2014). Transforming competitiveness into economic benefits: Does tourism stimulate economic growth in more competitive destinations? Tourism Management, 40, 137-140. https://doi.org/10.1016/j.tourman.2013.06.003

*** World Economic Forum. The Global Competitiveness Report 2018-2019, WEF: Cologny, Switzerland, 2018. http://www.ocean healthindex.org/methodology/components/tourism-competitiveness-index-tci

Article history: Received: 11.05.2021 Revised: 06.07.2021 Accepted: 12.08.2021 Available online: 01.09.2021 